\title{
Haemodynamic effect of deslanoside at rest and during exercise in patients with chronic bronchitis
}

\author{
V. Jezek and F. Schrijen \\ From Unité 14 de l'I.N.S.E.R.M., Nancy, France
}

The effect of intravenously administered deslanoside (Cedilanid) was studied in 24 patients with chronic bronchitis at rest and during exercise. No changes in ventilation, blood gases, and oxygen consumption were observed. In the patients without right heart failure, deslanoside induced a slight reduction in cardiac output, right ventricular end-diastolic and pulmonary arterial wedge pressures, and increase of systemic and pulmonary vascular resistances. The effect of deslanoside was different in the patients with right heart failure: an increase of cardiac output, stroke volume, right and left ventricular stroke work and stroke power, and a more pronounced decrease of $R V$ end-diastolic and pulmonary arterial wedge pressures were observed, with no changes in vascular resistances. We failed to find a significant improvement in cardiac performance after deslanoside during exercise. The effect of deslanoside does not seem to be related to arterial hypoxaemia or hypercapnic acidosis at rest.

The effect of digitalis glucosides has been studied by different authors (Ferrer and Harvey, 1959; Gray, Williams, and Gray, 1952; Mounsey et al., 1952; Berglund, Widimsky, and Malmberg, 1963). Particular attention has been drawn to the changes in pulmonary arterial and right ventricular pressures, but pulmonary arterial wedge or left heart pressures have been measured only occasionally. Therefore, we have little information about the changes of pulmonary vascular resistance in acute digitalization. We know only one paper (Berglund et al., 1963) which deals with the effect of digitalis in exercising patients.

We tried to study the effect of acute digitalization in a group of patients with chronic bronchitis sufficiently large for statistical analysis.

\section{Patients and examination procedure}

The study was made in 24 patients with chronic bronchitis, the diagnosis being made on the basis of a positive history of chronic productive cough. All the patients were of a physical and mental state to understand the nature and full circumstances of the investigation, and all of them assented to take part in the study, though they realized that it was not expected to be of direct advantage to themselves. Complete obstructive syndrome according to spirography was present in 67 per cent of the cases and normal spirographic values were observed in 4 cases only. Arterial hypoxaemia $\left(\mathrm{S}_{\mathrm{a}} \mathrm{O}_{2}\right.$

Received Io April 1972. less than $94 \%$ ) was present in 75 per cent, arterial hypercapnia $\left(\mathrm{P}_{\mathrm{a}} \mathrm{CO}_{2}\right.$ over $\left.43 \mathrm{mmHg}\right)$ in 71 per cent, and pulmonary arterial hypertension at rest $\left(\overline{\mathbf{P}}_{\mathbf{P A}}\right.$ over 20 $\mathrm{mmHg}$ ) in 79 per cent of the cases. No patient received digitalis glycosides at least 4 weeks before the study and no patient was in the period of acute respiratory insufficiency. No patient had evidence of valvular disease, atherosclerosis, or previous myocardial infarction.

When the diastolic systemic pressure was above 90 $\mathrm{mmHg}$, the patient was omitted from the study.

The patients were divided into the following groups: Group I includes 9 patients without any history of cardiac failure, Group 2 includes 6 patients with a positive history of cardiac failure from 4 weeks to 2 years before the study, and Group 3 includes 9 patients with signs of right heart failure (leg oedema, liver congestion) at the time of catheterization. No patients had clinical or laboratory signs of tricuspid insufficiency.

Catheterizations were performed in the postprandial state, without premedication, by Cournand catheters No. 7 and 8 introduced via the antecubital vein. Zero pressure level was placed $10 \mathrm{~cm}$ above the catheterization table. Ventilation, oxygen consumption, and carbon dioxide output were registered in the Metabograph. ${ }^{1}$ The analyses of blood gases were made in the Radiometer $^{2}$ equipment using Astrup's technique; blood oxygen capacity was measured in the Van Slyke apparatus. Arterial blood was withdrawn from a Cournand needle inserted in the brachial artery.

After introduction of the catheter in the wedge position and insertion of the needle in the brachial artery,

\footnotetext{
1 Metabo, Lausanne, Switzerland.

2 Radiometer, Copenhagen, Denmark.
} 
the patient breathed in a mask connected to the Metabograph. Pulmonary wedge, pulmonary arterial, right ventricular, and brachial artery pressures were recorded and the blood for analysis was withdrawn after ro minutes steady state. This procedure was repeated after pedalling (Io minutes on the average) on the bicycle ergometer in the supine position. The work load was $40 \mathrm{~W}$ for 18 patients and $20 \mathrm{~W}$ for 3 . Three patients were not able to exercise.

Immediately after exercise, a dose of $0.6 \mathrm{mg}$ deslanoside diluted in $10 \mathrm{ml}$ isotonic saline was introduced via the catheter. The same examination procedure and measurements were repeated after a rest of $30-40$ minutes.

Cardiac output was calculated according to the Fick method. The pre-ejection period and systolic ejection time index were derived from the brachial artery pressure curve according to Weissler, Harris, and Schoenfeld (1968). In 6 patients from another study, it was shown that the systolic ejection time calculated from the brachial artery and the ascending aorta pressure curves are identical. The mean systolic pressures for the calculation of ventricular work, ventricular power, and tension-time index were obtained by planimetry from the brachial artery and pulmonary artery pressure curves. Vascular resistances, ventricular work, stroke work, stroke power, and stroke tension-time index (Sarnoff et al., 1958), and mean systolic ejection rate were calculated by the usual formulae. Pulmonary artery wedge pressure was used instead of left ventricular end-diastolic pressure for the calculation of left ventricular work.

Statistical analysis was made by simple or paired t-test and by calculation of correlation coefficients. The differences in mean pulmonary arterial pressure and pulmonary vascular resistance between two exercise periods (before and after deslanoside) were not evaluated statistically because they are diminished by repeated exercise itself (Widimsky, Berglund, and Malmberg, 1963).

\section{Results}

\section{Differences between groups at rest}

The results are summarized in Table I. Groups I and 2 differ only in the values of end-diastolic and

\section{TABLE I Haemodynamic changes after deslanoside in patients recovering from cardiac failure (Group 2)}

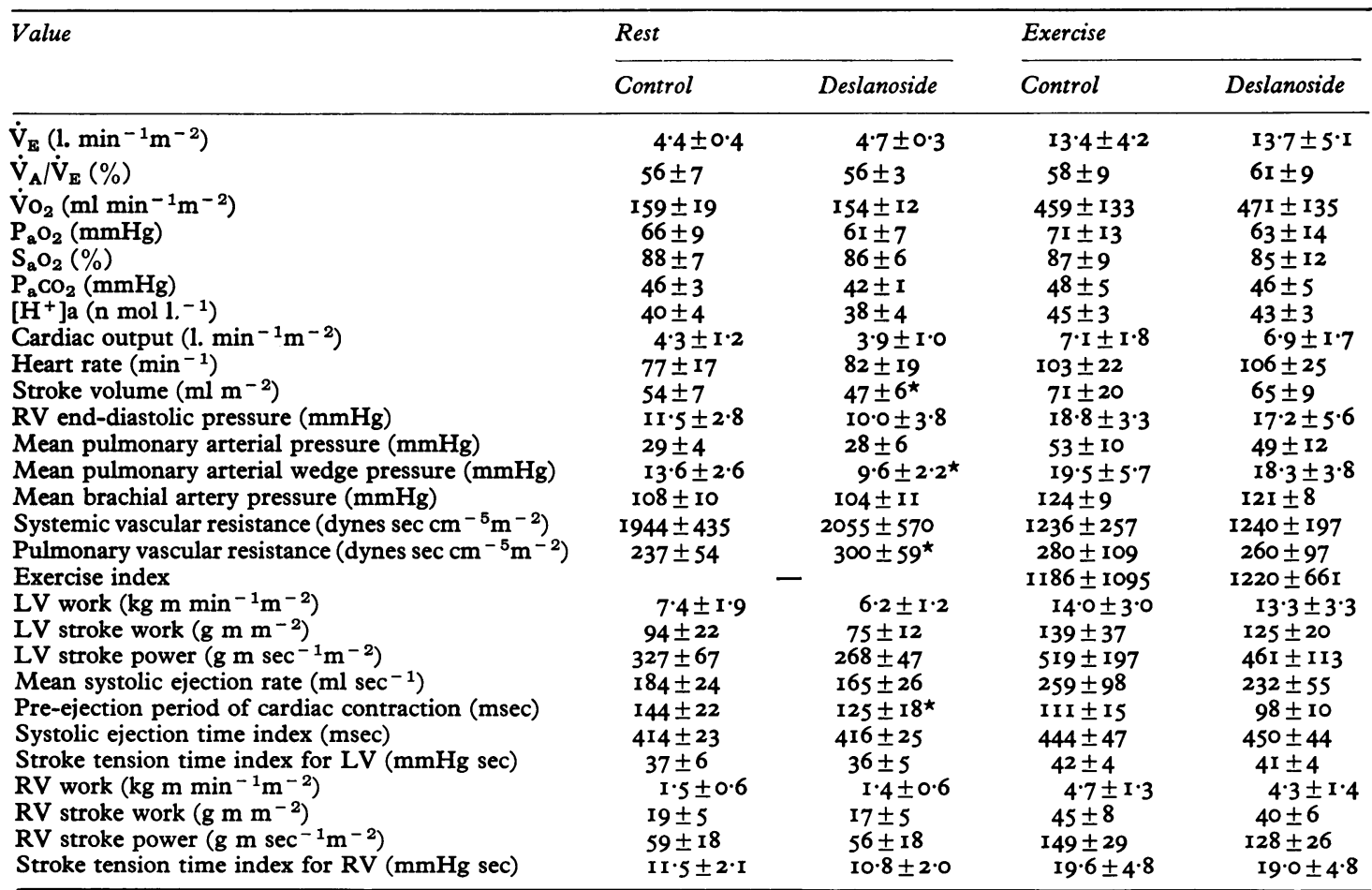

All values are given as a mean $\pm I$ standard deviation. Values during exercise were obtained in 5 patients of Group 2 and in 7 patients of Group 3 .

Statistical significance of the differences between control period and the measurements after deslanoside: ${ }^{\star} P<0.05 ; \dagger P<0.01$; $\ddagger \mathbf{P}<0.001$.

Symbols used in the Tables: $\dot{\mathrm{V}}_{\mathrm{E}}=$ global ventilation; $\dot{\mathrm{V}}_{\mathrm{A}}=$ alveolar ventilation; $\dot{\mathrm{V}}_{\mathbf{2}}=$ oxygen consumption. $\mathrm{P}_{\mathrm{a}} \mathrm{O}_{2}=$ arterial oxygen tension; $\mathrm{S}_{\mathrm{a}} \mathrm{O}_{2}=$ arterial oxygen saturation; $\mathrm{P}_{\mathrm{a}} \mathrm{CO}_{2}=$ arterial carbon dioxide tension; $\left[\mathrm{H}^{+}\right] \mathrm{a}=$ arterial hydrogen ions. Exercise index $=$ difference between cardiac output at rest and during exercise divided by the difference of oxygen consumption. 
pulmonary arterial pressures. Group 3 differs from others in body surface area, RV/TLC ratio, blood oxygen capacity, arterial $\mathrm{CO}_{2}$ tension, stroke volume, and right heart pressures.

Effect of deslanoside on cardiorespiratory parameters (Tables 2, 3, and 4)

Neither ventilation and oxygen consumption nor blood gases were influenced by the administration of deslanoside.

Cardiac output was slightly reduced in Group I and augmented in Group 3. Similar but insignificant changes were observed during exercise. Heart rate was slower after deslanoside only in Group 3 at rest. Stroke volume increased significantly in Group 3 and decreased slightly in others.

Right ventricular end-diastolic pressure was slightly reduced in Group I and more significantly reduced in Group 3. Pulmonary arterial and systemic arterial pressures did not change in any group. A slight but significant reduction was observed in pulmonary wedge pressure in all groups. Systemic and pulmonary vascular resistances increased significantly in Group I but not in the others.

Right and left ventricular work, stroke work, stroke power, and mean systolic ejection rate increased after deslanoside in Group 3 only. No significant changes in right and left stroke tensiontime indexes were found. The pre-ejection period was reduced in all subjects at rest but not significantly in exercise. We did not observe any changes in the systolic ejection time index.

\section{Relations between changes observed}

Correlation coefficients are summarized in Table 5. They indicate that the effect of deslanoside is well shown both for the left and right ventricle: there exists a significant correlation between right and left ventricular stroke work, stroke power, stroke tension-time index, and between end-diastolic and pulmonary arterial wedge pressures.

The changes of systolic ejection time index are correlated with those of stroke tension-time index and less significantly with left ventricular stroke

TABLE 2 Spirography, blood gases, and haemodynamics at rest in the 3 groups

\begin{tabular}{|c|c|c|c|c|c|c|}
\hline \multirow[t]{2}{*}{ Value } & \multirow{2}{*}{$\begin{array}{l}\text { Group I } \\
\text { ( } 9 \text { patients) }\end{array}$} & \multirow{2}{*}{$\begin{array}{l}\text { Group } 2 \\
\text { (6 patients) }\end{array}$} & \multirow{2}{*}{$\begin{array}{l}\text { Group } 3 \\
\text { (9 patients) }\end{array}$} & \multicolumn{3}{|c|}{ Statistical difference } \\
\hline & & & & $I-2$ & $I-3$ & $2-3$ \\
\hline Age (yr) & $\begin{array}{l}57 \cdot 0 \pm 11 \cdot 7 \\
39-74\end{array}$ & $\begin{array}{l}57 \cdot 2 \pm 6 \cdot 4 \\
47-62\end{array}$ & $\begin{array}{l}60 \cdot 4 \pm 6 \cdot 7 \\
47-68\end{array}$ & NS & NS & NS \\
\hline Body surface area $\left(\mathrm{m}^{2}\right)$ & $\begin{array}{l}I \cdot 68 \pm 0 \cdot 11 \\
I \cdot 48-I \cdot 8 I\end{array}$ & $\begin{array}{l}I \cdot 77 \pm 0 \cdot 12 \\
I \cdot 64-I \cdot 96\end{array}$ & $\begin{array}{l}1.83 \pm 0.17 \\
1.63-2.06\end{array}$ & NS & $P<0.05$ & NS \\
\hline FEV $_{1 \cdot 0} /$ vital capacity $(\%)$ & $\begin{array}{l}65 \pm 12 \\
44-77\end{array}$ & $\begin{array}{l}66 \pm 8 \\
56-75\end{array}$ & $\begin{array}{l}59 \pm 8 \\
48-67\end{array}$ & NS & NS & NS \\
\hline $\begin{array}{l}\text { Residual volume/total lung capacity } \\
(\%)\end{array}$ & $\begin{array}{l}29 \pm 4 \\
22-34\end{array}$ & $\begin{array}{l}27 \pm 4 \\
22-33\end{array}$ & $\begin{array}{l}32 \pm 3 \\
26-35\end{array}$ & NS & NS & $P<0.05$ \\
\hline $\mathrm{O}_{2}$ capacity $\left(\mathrm{ml} \mathrm{I}^{-1}\right)$ & $\begin{array}{l}187 \pm 14 \\
160-207\end{array}$ & $\begin{array}{l}201 \pm 26 \\
197-240\end{array}$ & $\begin{array}{l}222 \pm 29 \\
179-267\end{array}$ & NS & $P<0.01$ & \\
\hline $\mathrm{P}_{\mathrm{a}} \mathrm{O}_{2}(\mathrm{mmHg})$ & $\begin{array}{l}64 \pm \text { II } \\
52-84\end{array}$ & $\begin{array}{l}66 \pm 9 \\
51-76\end{array}$ & $\begin{array}{l}62 \pm 12 \\
50-86\end{array}$ & NS & NS & NS \\
\hline $\mathrm{S}_{\mathrm{a}} \mathrm{O}_{2}(\%)$ & $\begin{array}{l}84 \pm 9 \\
70-96\end{array}$ & $\begin{array}{l}88 \pm 7 \\
78-98\end{array}$ & $\begin{array}{l}82 \pm 10 \\
65-95\end{array}$ & NS & NS & NS \\
\hline $\mathrm{P}_{\mathrm{a}} \mathrm{CO}_{2}(\mathrm{mmHg})$ & $\begin{array}{l}48 \pm 13 \\
3 I-68\end{array}$ & $\begin{array}{l}46 \pm 3 \\
43-50\end{array}$ & $\begin{array}{l}56 \pm 10 \\
43-77\end{array}$ & NS & NS & $P<0.05$ \\
\hline$\left[\mathrm{H}^{+}\right] \mathrm{a}\left(\mathrm{n} \mathrm{mol} \mathrm{I}^{-1}\right)$ & $\begin{array}{l}39 \pm 5 \\
30-45\end{array}$ & $\begin{array}{l}40 \pm 4 \\
36-46\end{array}$ & $\begin{array}{l}4 I \pm 4 \\
33-49\end{array}$ & NS & NS & NS \\
\hline Cardiac output $\left(1 . \mathrm{min}^{-1} \mathrm{~m}^{-2}\right)$ & $\begin{array}{l}4 \cdot 3 \pm I \cdot 2 \\
2 \cdot 2-5 \cdot 9\end{array}$ & $\begin{array}{l}4 \cdot 3 \pm I \cdot 2 \\
2 \cdot 9-5 \cdot 8\end{array}$ & $\begin{array}{l}3 \cdot 1 \pm 1 \cdot 0 \\
2 \cdot 2-5 \cdot 1\end{array}$ & NS & NS & NS \\
\hline Heart rate $\left(\min ^{-1}\right)$ & $\begin{array}{l}82 \pm 12 \\
69-105\end{array}$ & $\begin{array}{l}77 \pm 17 \\
58-105\end{array}$ & $\begin{array}{l}91 \pm 12 \\
75-116\end{array}$ & NS & NS & NS \\
\hline Stroke volume $\left(\mathrm{ml} \mathrm{m}^{-2}\right)$ & $\begin{array}{l}48 \pm 10 \\
29-62\end{array}$ & $\begin{array}{l}54 \pm 7 \\
45-64\end{array}$ & $\begin{array}{l}35 \pm 12 \\
20-56\end{array}$ & NS & $P<0.02$ & $P<0.0 I$ \\
\hline $\mathrm{RV}$ end-diastolic pressure (mmHg) & $\begin{array}{l}7 \cdot 7 \pm 2 \cdot 4 \\
4-1 I\end{array}$ & $\begin{array}{l}11 \cdot 5 \pm 2 \cdot 8 \\
8-14\end{array}$ & $\begin{array}{l}12 \cdot 0 \pm 3 \cdot 4 \\
7-18\end{array}$ & $P<0.02$ & $P<0.01$ & NS \\
\hline $\begin{array}{l}\text { Mean pulmonary arterial pressure } \\
(\mathrm{mmHg})\end{array}$ & $\begin{array}{l}24 \pm 6 \\
16-35\end{array}$ & $\begin{array}{l}29 \pm 4 \\
23-35\end{array}$ & $\begin{array}{l}33 \pm 8 \\
25-41\end{array}$ & NS & $\mathbf{P}<0.05$ & NS \\
\hline $\begin{array}{l}\text { Mean pulmonary arterial wedge } \\
\text { pressure (mmHg) }\end{array}$ & $\begin{array}{l}9 \cdot 9 \pm 2 \cdot 7 \\
5-13\end{array}$ & $\begin{array}{l}13 \cdot 6 \pm 2 \cdot 6 \\
10-16\end{array}$ & $\begin{array}{l}13 \cdot 2 \pm 2 \cdot 6 \\
9-18\end{array}$ & $\mathbf{P}<0.02$ & $\mathbf{P}<0.02$ & NS \\
\hline
\end{tabular}

All values are given as a mean $\pm I$ standard deviation, with the range below. $F_{E V} \cdot 0=$ forced expiratory volume. For other symbols see footnote to Table $I$. 
TABLE 3 Haemodynamic changes after deslanoside in patients without cardiac failure (Group I)

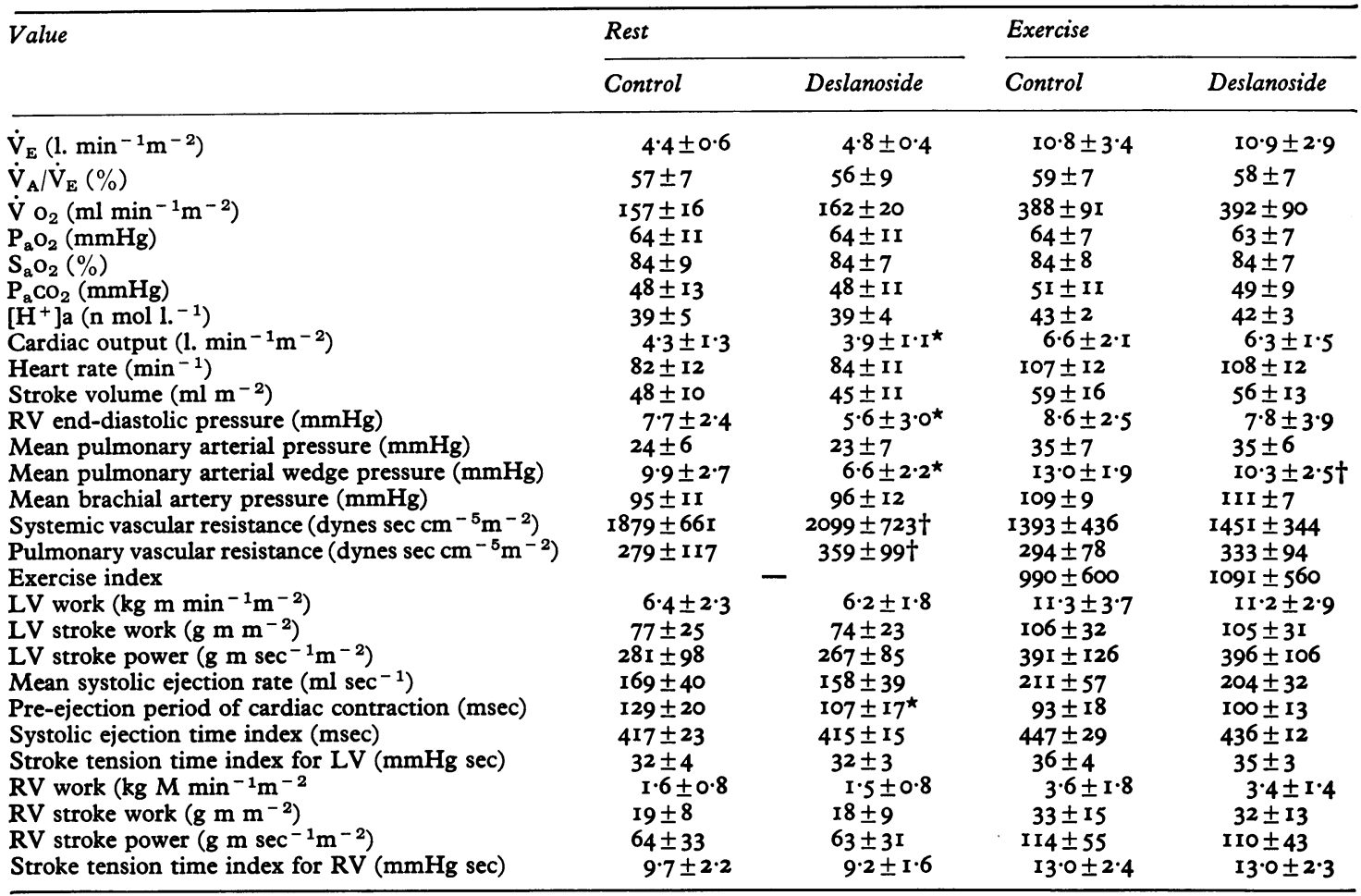

work. The mean systolic ejection rate shows a significant correlation both with right and left ventricular stroke work and stroke power changes.

The decrease of end-diastolic and pulmonary arterial wedge pressures shows no relation to the changes of any other haemodynamic value.

\section{Discussion}

An evaluation of the long-term treatment of chronic heart failure complicating chronic bronchitis by digitalis glycosides is not completely uniform: an improvement of the clinical picture of patients is described by a majority of authors (McMichael, 1954; Mack and Snider, 1956) but it is also denied (Castaing, 1955). However, evaluation is difficult because some patients were simultaneously given other treatment for respiratory insufficiency.

The acute effect of digitalis glycosides in healthy subjects and in cardiac patients without any history of cardiac failure is usually considered as minimal: no changes (Dresdale et al., 1959; Goodyer, Chetrick, and Huvos, 1960) or a slight decrease (Williams, Zohman, and Ratner, 1958) in cardiac output and slight increase in systemic vascular resistance (Williams et al., I958) were described. Simi- lar changes were observed by Ferrer and Harvey (1959) and in some patients of Berglund et al. (1963) in the patients with chronic bronchitis without chronic heart failure. Nevertheless, it was shown (Braunwald, Ross, and Sonnenblick, 1967) that acute digitalization also improves the contractile state of the nonfailing heart. It corroborates our results for compensated patients where a slight but significant decrease in end-diastolic pressure was found.

More pronounced is the effect of deslanoside in patients suffering from chronic heart failure. All our cases showed a significant improvement of cardiac function (increased stroke volume associated with a decrease of RV end-diastolic pressure). Some previous papers conclude that, generally, the effect of digitalis glycosides in chronic cor pulmonale is minimal (Ferrer and Harvey, 1959; Berglund et al., 1963). This impression may be obtained by an observation that in right heart failure complicating primordial disease of the left heart, the increase in stroke volume and a reduction in end-diastolic pressure are more pronounced than in cor pulmonale, and that they are accompanied by a reduction of pulmonary arterial pressure (Ferrer, Conroy, and 
Harvey, 1960; Parker et al., 1969) which does not occur in cor pulmonale. Also many studies are concerned with patients with and without chronic heart failure. Regarding only decompensated patients, the results of previous studies are comparable with ours, i.e. they indicate an improved cardiac function in chronic bronchitis after digitalis.

The effect of digitalis glycosides in exercise was studied by Berglund et al. (1963) in 4 patients. They found a reduction of $R V$ end-diastolic pressure but

TABLE 4 Haemodynamic changes after deslanoside in patients with cardiac failure (Group 3)

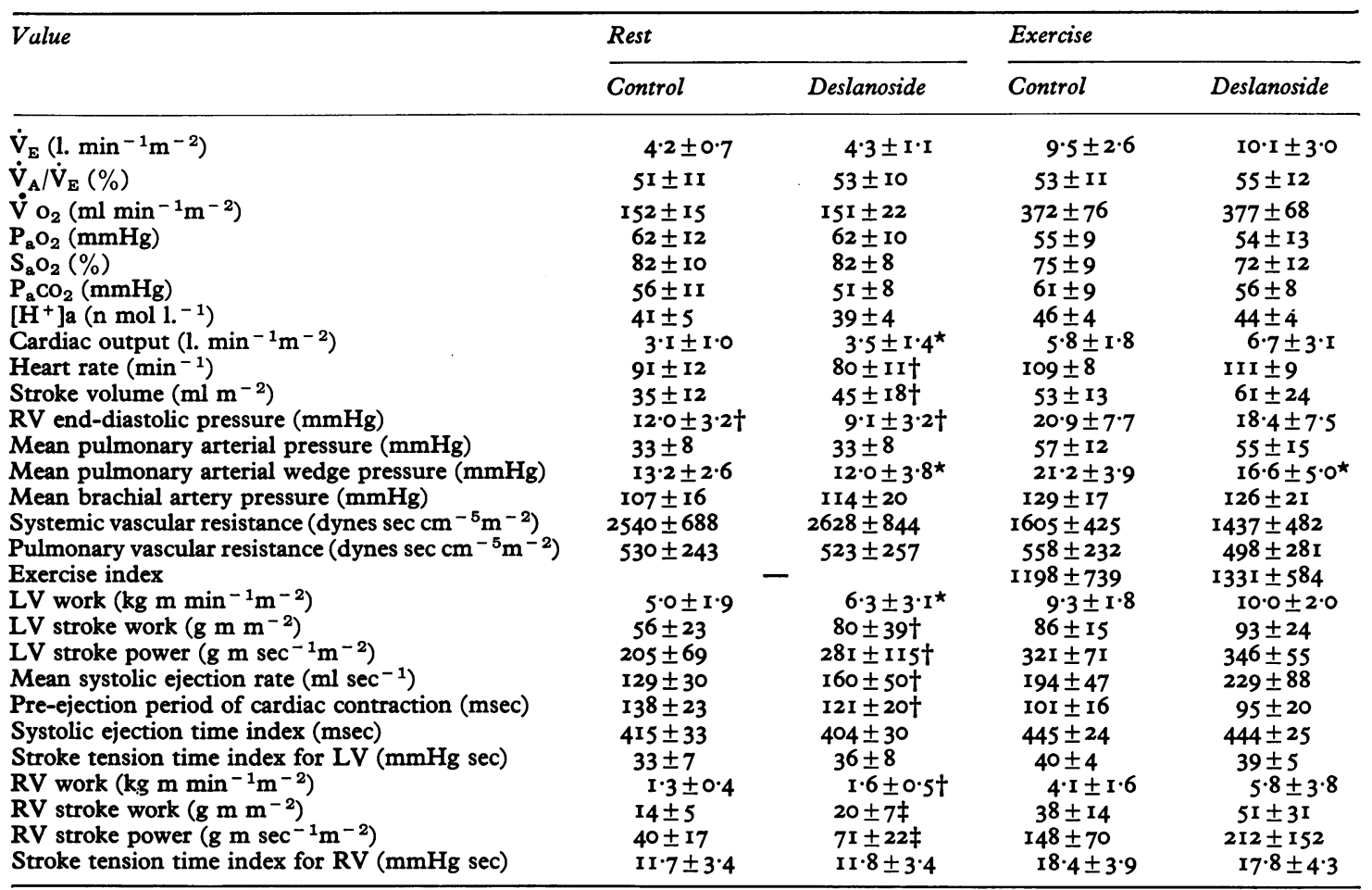

TABLE 5 Interrelations between changes after deslanoside at rest in parameters of cardiac function

\begin{tabular}{|c|c|c|c|c|c|c|c|c|c|c|c|}
\hline & $\begin{array}{l}\text { Stroke } \\
\text { volume }\end{array}$ & $\begin{array}{l}\text { Systolic } \\
\text { ejection } \\
\text { time } \\
\text { index }\end{array}$ & $\begin{array}{l}L V \\
\text { stroke } \\
\text { work }\end{array}$ & $\begin{array}{l}L V \\
\text { stroke } \\
\text { power }\end{array}$ & $\begin{array}{l}\text { Mean } \\
\text { systolic } \\
\text { ejection } \\
\text { rate }\end{array}$ & $\begin{array}{l}\text { Stroke } \\
\text { tension } \\
\text { time } \\
\text { index } \\
\text { for LV }\end{array}$ & $\begin{array}{l}R V \\
\text { stroke } \\
\text { work }\end{array}$ & $\begin{array}{l}R V \\
\text { stroke } \\
\text { power }\end{array}$ & $\begin{array}{l}\text { Stroke } \\
\text { tension } \\
\text { time } \\
\text { index } \\
\text { for } R V\end{array}$ & $\begin{array}{l}R V \\
\text { end- } \\
\text { diastolic } \\
\text { pressure }\end{array}$ & $\begin{array}{l}\text { Mean } \\
\text { pulmonary } \\
\text { arterial } \\
\text { wedge } \\
\text { pressure }\end{array}$ \\
\hline $\begin{array}{l}\text { Stroke volume } \\
\text { Systolic ejection time }\end{array}$ & - & 0.149 & $0.947 \ddagger$ & $0.927 \ddagger$ & $0.944 \ddagger$ & 0.286 & $0.660 \ddagger$ & $0.482 \ddagger$ & 0.259 & 0.070 & 0.065 \\
\hline $\begin{array}{l}\text { index } \\
\text { LV stroke work }\end{array}$ & & - & $\underline{0.337}^{\star}$ & $\begin{array}{l}0.272 \\
0.953 \ddagger\end{array}$ & $\begin{array}{l}0.274 \\
0.854 \ddagger\end{array}$ & $\begin{array}{l}0.440 t \\
0.417 t\end{array}$ & $\begin{array}{l}0.073 \\
0.554 \ddagger\end{array}$ & $\begin{array}{l}0.034 \\
0.328^{\star}\end{array}$ & $\begin{array}{l}0.188 \\
0.153\end{array}$ & $\begin{array}{l}0.073 \\
0.180\end{array}$ & $\begin{array}{l}0.056 \\
0.020\end{array}$ \\
\hline & & & & ד & $0.914 \ddagger$ & 0.206 & $0.540 \ddagger$ & $0.344^{\star}$ & 0.069 & 0.138 & 0.137 \\
\hline $\begin{array}{l}\text { rate } \\
\text { Stroke tension time }\end{array}$ & & & & & - & 0.068 & $0.669 \ddagger$ & $0.515 \ddagger$ & 0.212 & 0.006 & 0.130 \\
\hline $\begin{array}{c}\text { index for LV } \\
\text { RV stroke work }\end{array}$ & & & & & & - & $\underline{0.260}$ & $\begin{array}{l}0.163 \\
0.955 \ddagger\end{array}$ & $\begin{array}{l}0.363^{\star} \\
0.286\end{array}$ & $\begin{array}{l}0.026 \\
0.022\end{array}$ & $\begin{array}{l}0.116 \\
0 \cdot 106\end{array}$ \\
\hline $\begin{array}{l}\text { RV stroke power } \\
\text { Stroke tension time }\end{array}$ & & & & & & & & - & 0.103 & 0.106 & 0.038 \\
\hline $\begin{array}{l}\text { index for RV } \\
\text { RV end-diastolic press }\end{array}$ & sure & & & & & & & & - & $\frac{0.272}{-}$ & $\begin{array}{l}0.216 \\
0.602 \ddagger\end{array}$ \\
\hline
\end{tabular}

Symbols of statistical significance are the same as in Tables 2-4 
no increase in stroke volume as compared with exercise values without digitalis, and they concluded that digitalis had a minimal effect on exercise haemodynamics. This is not in disagreement with our results. If we classify the cardiac performance during exercise according to the criteria of Ross et al. (1966), we obtain the following results for I2 patients suffering from or recovering from chronic heart failure. Before deslanoside, a normal response in 17 per cent, abnormal response in 50 per cent, and depressed cardiac function in 33 per cent of the cases; after deslanoside, the results are not different except for 2 patients whose depressed function was changed to abnormal response. Therefore, deslanoside is not capable of improving significantly an abnormal or depressed myocardial performance during exercise in chronic bronchitis.

The changes of pulmonary vascular resistance after digitalis are not simple to explain. An increase in pulmonary vascular resistance was observed in isolated lung preparations with constant flow (Aviado, 1956; Kim and Aviado, 196r), indicating a direct constrictive action of digitalis glycosides on the lung vessels. This mechanism may explain the increased pulmonary vascular resistance seen in all patients in Groups I and 2. On the other hand, a drop in pulmonary resistance was observed in left heart failure after digitalis. The behaviour of pulmonary vascular resistance does not seem to be in direct relation to cardiac function; Davis, Howell, and Hyatt (1955) found an improvement in cardiac function after digoxin in the animals in which right ventricular output resistance was fixed by pulmonary artery constriction.

It is not clear why pulmonary vascular resistance, increased by vasoconstrictive action of digitalis glycosides in animals and probably also in subjects without cardiac failure, decreases in patients with left heart failure and does not change in our Group 3. Kim and Aviado (I96I) suggest two possible explanations: (a) that the reduction in left ventricular filling pressure inactivates the pulmonary vasoconstriction reflex of the left atrium, and (b) that the increase in vagal tone brought about by digitalis extends to dilate the pulmonary vessels. The second explanation does not seem to be probable because the same dose of deslanoside was injected in all subjects, with different results. As for left ventricular filling pressure, we measured it directly in 2 patients only, and pulmonary arterial wedge pressure does not always represent an identical value of this pressure in pulmonary diseases (Jezek and Herles, 1969). Nevertheless, there exists a significant correlation between the changes in pulmonary vascular resistance and left ventricular stroke work in our patients $(\mathrm{r}=-0.438, \mathrm{P}<0.05)$, indicating a possible relation between the improvement in left ventricular function and the behaviour of pulmonary vascular resistance.

A shortening of the pre-ejection period may be considered as a sign of the positive inotropic action of deslanoside. This period was slightly prolonged in decompensated patients in whom also the effect of deslanoside is more pronounced. It corresponds to our previous results (Jezek, I963; Jezek, Daum, and Serf, 1964).

Possible negative influence of hypoxaemia or hypercapnic acidosis on the effect of digitalis in chronic bronchitis was discussed by Berglund et al., 1963. Recently, Donlon and Yu (1969) showed in an acute experiment that the cardiovascular response of hypoxic myocardium to strophanthin, though significant, is lower than in normal oxygen conditions. In our study, $\mathrm{S}_{\mathrm{a}} \mathrm{O}_{2}$ before deslanoside at rest varied from 70 to 96 per cent in compensated patients and from 65 to 95 per cent in the cases with chronic heart failure; $\mathrm{P}_{\mathrm{a}} \mathrm{CO}_{2}$ was from $3 \mathrm{I}$ to 68 mmHg and from 43 to $77 \mathrm{mmHg}$, respectively. Despite this large scale, we failed to find any relation between the values of blood gases and the haemodynamic changes after deslanoside.

Our results indicate that, despite unchanged pulmonary arterial pressure and variable changes of pulmonary vascular resistance, treatment with deslanoside represents an important improvement in cardiac function for patients with chronic bronchitis and chronic heart failure.

We wish to thank Miss F. Poincelot and Mr. J. C. Henqual for their skilful technical assistance; and Sandoz Laboratories for kindly supplying deslanoside.

\section{References}

Aviado, D. M. (1965). The Lung Circulation, p. 638. Pergamon Press, Oxford.

Berglund, E., Widimsky, J., and Malmberg, R. (1963). Lack of effect of digitalis in patients with pulmonary disease with and without heart failure. American fournal of Cardiology, 11, 477 .

Braunwald, E., Ross, J., and Sonnenblick, E. H. (1967). Mechanisms of Contraction of the Normal and Failing Heart, pp. I20 and I7I. Little, Brown, Boston; Churchill, London.

Castaing, R. (1955). Le coeur des pulmonaires chroniques. Fournal de Médecine de Bordeaux et du Sud-Ouest, 132, 135.

Davis, J. O., Howell, D. S., and Hyatt, R. E. (1955). Effects of acute and chronic digoxin administration in dogs with right-sided congestive heart failure produced by pulmonary artery constriction. Circulation Research, 3, 259.

Donlon, J. V., and Yu, P. N. (1969). Cardiovascular response of hypoxic myocardium to acetyl strophanthidin. American Heart fournal, 78, 238.

Dresdale, D. T., Yuceoglu, Y. Z., Michtom, R. J., Schultz, M., and Lunger, M. (1959). Effects of lanatoside C on cardiovascular hemodynamics; acute digitalizing doses in subjects with normal hearts and with heart disease without failure. American fournal of Cardiology, 4, 88. 
Ferrer, M. I., Conroy, R. J., and Harvey, R. M. (I960). Some effects of digoxin upon the heart and circulation in man, digoxin in combined (left and right) ventricular failure. Circulation, 21, 372.

Ferrer, M. I., and Harvey, R. M. (1959). Decompensated pulmonary heart disease with a note on the effect of digitalis. In Pulmonary Circulation, An International Symposium, p. I7I. Ed. by W. R. Adams and I. Veith. Grune and Stratton, New York.

Goodyer, A. V., Chetrick, A., and Huvos, A. (1960). The effect of lanatoside $\mathrm{C}$ on the response of the human cardiac output to walking exercise. Yale fournal of Biology and Medicine, 32, 265.

Gray, F. D., Williams, M. H., and Gray, F. G. (1952). The circulatory and ventilatory changes in chronic pulmonary disease as affected by lanatoside C. American Heart fournal, 44, 517.

Jezek, V. (1963). Clinical value of the polygraphic tracing in the study of the sequence of events during cardiac contraction. Cardiologia, 43, 298.

Jezek, V., Daum, S., and Serf, B. (1964). Heart contraction in chronic cor pulmonale. Cor et Vasa, 6, 85 .

Jezek, V., and Herles, F. (1969). Uneven distribution of pulmonary arterial wedge pressure in chronic bronchitis and emphysema. Cardiologia, 54, I64.

Kim, Y. S., and Aviado, D. M. (I96I). Digitalis and the pulmonary circulation. American Heart fournal, 62, 680 .

McMichael, J. (1954). Treatment of chronic cor pulmonale. Acta Cardiologica, 9, 295.

Mack, I., and Snider, G. L. (1956). Respiratory insufficiency and chronic cor pulmonale. Circulation, 13, 419.
Mounsey, J. P. D., Ritzmann, L. W., Selverstone, N. J., Briscoe, W. A., and McLemore, G. A. (1952). Circulatory changes in severe pulmonary emphysema. British Heart fournal, 14, 153 .

Parker, J. O., West, R. O., Ledwich, J. R., and Di-Giorgi, S. (1969). The effect of acute digitalization on the hemodynamic response to exercise in coronary artery disease. Circulation, 40, 453.

Ross, J., Gault, J. H., Mason, D. T., Linhart, J. W., and Braunwald, E. (1966). Left ventricular performance during muscular exercise in patients with and without cardiac dysfunction. Circulation, 34, 597.

Sarnoff, S. J., Braunwald, E., Welch, G. H., Case, R. B., Stainsby, W. N., and Macruz, R. (1958). Hemodynamic determinants of oxygen consumption of the heart with special reference to the tension-time index. American fournal of Physiology, 192, 148.

Weissler, A. M., Harris, W. S., and Schoenfeld, C. D. (I968). Systolic time intervals in heart failure in man. Circulation, 37, 149.

Widimsky, J., Berglund, E., and Malmberg, R. (1963). Effect of repeated exercise on the lesser circulation. Fournal of Applied Physiology, 18, 983.

Williams, M. H., Zohman, L. R., and Ratner, A. C. (1958). Hemodynamic effects of cardiac glycosides on normal human subjects during rest and exercise. Fournal of Applied Physiology, 13, 417.

Requests for reprints to Dr. F. Schrijen, Unité I2 de l'I.N.S.E.R.M., B.P. 65, 54 Nancy, France. 